\title{
Alternative Assessment: The Impact of Self- assessment vs. Peer-assessment on Iranian Intermediate EFL Learners' Paragraph Writing Ability
}

\author{
Marzieh Ghazizadeh¹, Davood Taghipour Bazargani ${ }^{2, *}$ \\ 1 Department of English Language, Rasht Branch, Islamic Azad University, Rasht, Iran \\ ${ }^{2}$ Assistant Professor, Department of English Language, Rasht Branch, Islamic Azad University, Rasht, \\ Iran
}

Received 13 October 2018 Accepted 21 February 2019

\begin{abstract}
The present study was designed to investigate the effectiveness of two types of alternative assessment, namely self- and peer-assessment in improving paragraph writing ability of Iranian Intermediate EFL learners. In so doing, 45 female learners who were studying at Pardis institute in Rasht, and in the 18-22 age range, were selected among 90 participants based on their performance on OPT. The participants were randomly assigned to two experimental groups and one control group each consisting of 15 participants. A pre-test was administered to the three groups. Then, both experimental groups received 10-session treatments that were the use of self-assessment in the experimental group (A) and the use of peer-assessment in the experimental group (B). A post-test was then administered to all the three groups. A statistically significant difference was found between self, peer and traditional assessment. The results also revealed that the experimental group (B) that utilized peer-assessment achieved significantly higher proficiency in paragraph writing than the other two groups. Additionally, the experimental group (A) that received the use of self-assessment outperformed the control group. Based on the findings of this study, language teachers can utilize both kinds of alternative assessment investigated in this study (i.e. self-assessment and peer-assessment) to improve their learners' paragraph writing ability.
\end{abstract}

Keywords: Assessment, Alternative Assessment, Peer-assessment, Self-assessment, Paragraph Writing Ability 


\section{Introduction}

Writing has been an essential area in applied linguistics for more than half a century and is a domain of dynamic academic investigation and discussion. Lindsay and Knight (2006) state that learners write for many different reasons: "to pass on information and opinions, to ask questions, request or offer something, to entertain, to keep a record, to organize our thoughts, as part of the assessment process, and so on" (p. 85). It is very important in education today, so everyone wants to know the best way to teach it. But that can be a challenge because there are so many different ideas out there.

Writing is regarded not only a means of communicating and assessing understanding of content knowledge, but as a way of constructing knowledge. Yet, though writing is likely a beneficial activity in most, if not all, disciplines, it has been difficult to implement in content courses (Ryan, 2007). Writing assessment is useful primarily as a means of improving teaching and learning. It refers to an area of study that contains theories and practices that guide the evaluation of a writing task. It can be considered a combination of scholarship from composition studies and measurement theory within educational assessment. As Benson (2001) argues, learners become aware of their ability while assessing their language proficiency and their progress. By recognizing their weaknesses, they will then be able to seek help with these areas in which they need to improve. Finally, they will see how close or how distant their actual language proficiency is from the level they wish to achieve.

Writing is one of the main parts of education, and it is necessary both for students and for employees of all business sectors. The fact that the learners do not have interest in the paragraph writing leads them to be poor writers, have low scores in their courses, increase the errors in their homework, write run-on sentences and create incoherent paragraphs. According to Lynn (2011), many students have learned in high school to camouflage their lack of reading and writing skills, so it is often difficult for teachers to identify their weaknesses until students hand in papers or take exams. Then, writing deficiencies are obvious. It is unfortunate that, a lot of Iranian EFL learners have severe problems in writing ability. Khansir, Ahrami, and Hajivandi, (2013) mentioned that in countries such as Iran, where English is taught as a foreign language, it seems difficult to develop the ability of learners to a standard level. English in Iran is used as a foreign language and today the demand for learning English language among Iranian is growing. For this reason, it is important to say that academic writing involves many requirements that students must put into practice to avoid difficulties and complications at the moment of writing essays or report papers.

The primary purpose of any assessment should govern its design, its implementation, and the generation and dissemination of its results. According to Crooks (2001), assessment is "any process that provides information about the thinking, achievement or progress of students" (p. 1). Good assessment practices start with a pedagogically sound assignment description and learning goals for the writing task at hand. Assessment of student writing is a process. This process and performance in the class should occur at many different stages throughout the course and could come in many different forms. There is a wide range of assessments that are available for use in 
restructuring science assessment in the classroom. These types of assessments are traditional, dynamic, and alternative each of which includes various strategies.

Traditional tests enjoy a firm inquiry foundation and have appeared broadly conventional as a method for judging writing in various conditions. Traditional writing tests are regularly applied in research as well, for instance, to gather data of creative language use for investigations of second-language development in different situations (Weigle, 2002).

Alternative assessment procedures include checklists, rating scales, rubrics, journals, logs, videotapes and audiotapes, portfolio, conferences, diaries, self-assessment and peer-assessment. According to Brown and Hudson (1998), performance in self-assessment requires students to read a situation and decide how well they would respond to it. In a similar way, comprehension in self-assessments requires students to read a situation or write a passage and decide how well they would comprehend it or how well the writing was. According to Kollar and Fischer (2010), peer assessment can enhance students' learning through knowledge diffusion and exchange of ideas and motivate students to engage with course material more deeply.

\section{Literature Review}

Constructivists have stated that education should be learner-based and that "knowledge must develop and continue to change with the activity of the learner" (Driscoll, 2000, p. 379). Reformed vision of curriculum and constructivist learning theories call for a new type of assessment, the one that can be used as a part of instruction in order to aid and enhance the process of learning. It is about having a deep connection with promoting student learning, and there are various specific purposes for assessing but the common link is that of promoting students' understanding. Namely, a student who understands can explain, which means that students can interpret knowledge using their own words and argue the critical points knowing, not only what has been taught, but also identifying and applying what has been learned in practical situations.

Assessment reform shifts its attention from the mere use of traditional tests to more authentic methods of testing which are holistically performed by the active participation of the students, their peers and their teachers. This shift is an attempt to distance from the rigid and static tests and to approach more towards real-life tasks implemented in complex real-life situations (Tangdhanakanond, 2006). In contrast to traditional assessment, which is aligned with the transmission model of knowledge wherein students are empty vessels waiting to be filled by the teacher, alternative assessment takes its cue from the constructivist theory of knowledge which views students as creators of their own understanding. Alternative assessment asks students to show what they can do, that is to say, students are evaluated on what they integrate and produce rather than on what they are able to recall (Coombe, Folse, \& Hubly, 2007). A large number of novel approaches of assessment have hence been suggested which meant to develop the integration of learning and assessment by enhancing the engagement of students in the assessment tasks (Sluijsmans, Brand-Gruwel, vanMerrienboer, \& Bastiens, 2003). Research in this area has sought to explore whether alternative assessment is effective and what strategies 
and treatments teachers use for error correction. Researchers try to discover the effects of various assessments on students' immediate revisions and their longer term development as writers.

Alternative assessment is contextualized to both the classroom and the individual student and aims to put students in charge of their own learning and schema construction (Janisch, 2007). The learners become active participants in the process of learning by realizing their strength and weaknesses and in setting realistic learning goals (Luoma \& Tarnanen, 2003). Self-assessment is a process through which students learn about themselves (Dikel, 2005). Tan (2007) also argued for "self-assessment development practices that can develop and sustain students' selfassessment ability beyond its immediate programme of study" (p. 115). Peer assessment is one type of alternative assessment believed to enable learners to develop abilities and skills more than the teacher alone assessment (Cheng \& Warren, 2005). Peer assessment is believed to benefit learners by developing students' critical thinking (Alderson, 1985; Cheng \& Warren, 2005). Moreover, it is believed that if learners can be trained to assess their peer confidently and reliably, they will also be able to evaluate their own language skills to improve themselves (Cheng \& Warren, 2005).

\section{Assessment}

The assessment of writing has long been considered a problematic area for educational professionals, especially when it comes to evaluating the writing of EFL students. Many EFL teachers believe that assessment is a crucial element to develop the students' ability to evaluate their own performance leading to its improvement. Some scholars believe that assessment is the engine which drives the students' learning (Cowan, 2005).

\section{Traditional Assessment}

Belle defines traditional assessment as "evaluations that include standardized and classroom achievement tests with mostly closed-ended item, such as true/false, multiple choice, and fill-inthe blanks" (Belle, 1999, p. 6). This view implies that knowledge exists separately from the learner. Therefore, students work to accumulate knowledge rather than to construct it. This belief is grounded in a traditional approach to the educational endeavor based on Behaviorist theories. Teacher written or oral responses play a central role in most EFL writing classes in traditional assessment. Many teachers feel they must write substantial comments on papers to provide a reader reaction to students' efforts, to help them improve as writers and to justify the grade they have been given (Hyland, 2003).

\section{Alternative Assessment}

In recent years, language teachers have stepped up efforts to develop non-test assessment options that are nevertheless carefully designed and that adhere to the criteria for adequate assessment (Law \& Eckes, 2007). Sometimes such innovations are referred to as alternative assessment, if only to distinguish them from traditional formal tests. Alternative assessment presents a process that provides an opportunity for the meaningful integration of curriculum, instruction and 
assessment. The alternative assessment models are based on 'the shared practice' as defined in Elwood \& Klenowski (2002) on creating communities of shared practice where nothing in the assessment process is hidden. Their research suggests that to improve learning and indeed teaching, educational assessment must be formative in both function and purpose as well as must place a student in the very center of the assessment. Alternative assessment procedures include checklists, rating scales, rubrics, journals, logs, videotapes and audiotapes, portfolio, conferences, observations, diaries, self-assessment and peer-assessment. Several alternatives in assessment will be briefly discussed below.

\section{Self-Assessment}

Andrade and Du (2007) provide a helpful definition of self-assessment that focuses on the formative learning that it can promote:

Self-assessment is a process of formative assessment during which students reflect on and evaluate the quality of their work and their learning, judge the degree to which they reflect explicitly stated goals or criteria, identify strengths and weaknesses in their work, and revise accordingly. (p. 160)

\section{Peer-Assessment}

Patri (2002) proposes that using peer assessment training could help students evaluate their peer performance comparable to their teachers, even with learners of low level of language proficiency. Nakamura (2002) claims that understanding rating criteria in evaluating peers can help students to prepare their own presentation to reach their goal. In addition, many researchers believe that peer assessment can increase students' responsibility.

\section{Empirical Studies on Alternative Assessment}

Many empirical studies have been carried out on alternative assessment in different contexts. Different researchers have used various types of alternative assessment to evaluate the impact of alternative assessment on different skills and component of language. Contemporary assessment theories are viewing the role of assessment as the aspect that describes student's performance instead describing a measure of a student achievement related to the traditional curricula. Puegphrom and Chiramanee (2011) examined the efficiency of implementing peer-assessment on students' writing proficiency. Through cooperative working in groups of 3 students, the subjects' writing ability significantly improved. The improvement included the more accuracy in using grammatical elements, completeness of contents, and better idea organization. This can be attributed to the fact that in the process of peer assessment, learners could learn from the peer's error and make use of them in composing their own work.

Aydin (2010) carried out a qualitative research on portfolio keeping in English as a foreign language writing in Turkey aiming to investigate the problems encountered and contributions of portfolios to the language skills of EFL pre-service teachers. The sample group consists of 39 
pre-service teachers; a background questionnaire, interview a survey, and essays were used for data collection. The results indicated that portfolios significantly contribute to the writing skills. Moradan and Hedayati (2011) focused on the impact of portfolios and conferencing on Iranian EFL learners' writing skill. The result of this study showed that there was significant difference between performance of the two experimental groups and that of the control group on the posttest. No significant difference was found between the performance of the two experimental groups after implementing portfolios and conferencing techniques.

As for speaking ability, Ahangari, Rassekh-Alqol, and Ali Akbari (2013) examined the effect of peer assessment on oral presentation of Iranian EFL students. They obtained data through a Likert scale questionnaire of peer assessment. The results of their study specified a statistically significant difference among the groups. The findings of their study also suggested that peerassessment can enhance the speaking ability of learners if they are given a valid criterion or framework. This finding is in line with the study conducted by Patri (2002). He found that the self-assessment scores are, mostly, higher than the marks given by teachers in traditional assessment.

Birjandi and Hadidi Tamjid (2010) examined the effect of self-assessment in promoting Iranian EFL learners' motivation. Journal writing was used as the self-assessment technique for the experimental group. The results of their study revealed that a regular use of journal writing can promote the learners' motivation.

Implementing two techniques of self-assessment and conferencing, Firooz-Zareh (2006) investigated the relationship between alternative assessment techniques and Iranian learners' reading proficiency. The results of his research proved that alternative assessment techniques should be incorporated into instruction and assessment programs. Besharati (2004) did a similar research but focusing on the impact of alternative assessment on listening proficiency of Iranian EFL learners. His study produced similar outcomes which necessitates the implementation of peer and self-assessment techniques.

Enayat, Iraji and Momeni (2016) also investigated the effects of self- and peer-assessment on Iranian EFL learners' argumentative writing performance. According to the results of this research, providing the opportunity for the students to use self- and peer-assessments was helpful and influential in improving their argumentative writing ability. By providing alternative assessment techniques, learners could write better compositions. The results of this study showed significant change in the experimental group; therefore, the findings can help EFL teachers who like to help students develop strategies for their own learning, to help them find their strengths and weaknesses, and to help them become more autonomous.

Many studies have tried to find the effect of using alternative assessments in L1 and L2 instruction. However, the simultaneous effect of self and peer-assessment on Intermediate EFL learners' paragraph writing ability has not been explored in the context of Iran. In an attempt to fill this research gap, this study aimed to seek answers to the following questions: 
$\mathbf{R Q}_{1}$ : Does self-assessment have any statistically significant effect on Iranian Intermediate EFL learners' paragraph writing ability?

$\mathbf{R Q}_{2}$ : Does peer-assessment have any statistically significant effect on Iranian Intermediate EFL learners' paragraph writing ability?

$\mathbf{R Q}_{3}$ : Is there any statistically significant difference between the effects of self-assessment and peer-assessment on Iranian Intermediate EFL learners' paragraph writing ability?

\section{Method}

\section{Participants}

The study was conducted with a sample of 45 female intermediate-level EFL learners, in the 1822 age range, studying English at Pardis institute in Rasht, Iran. The total number of learners registered in the selected institute was 90 who were homogenized through OPT. The participants who got $31+$ in grammar and vocabulary, $8+$ in reading section and $8+$ in writing were selected. The participants were randomly assigned to three different groups. They were divided into two experimental groups and one control group. Each class consisted 15 participants. Experimental group (A) received the use of self-assessment as the treatment, and experimental group (B) received the use of peer-assessment as the treatment. In the control group, traditional teacher assessment was applied.

\section{Research Design}

The present study employed a true-experimental design since it had all the necessary characteristics of an experimental method including pretest, experimental groups, control group, treatment, placebo, and posttest. Randomization was used in selecting the participants of the study in order to eliminate potential biases or judgments. According to Farhady (2010), "random selection should be achieved in such a way that there is no bias exercised over one particular subject.

\section{Instrumentation}

The required data of this study was collected quantitatively. In addition, the main data gathering instruments in this study were paper and pencil tests. A pre-test, piloted before with 15 participants, was administered to the participants of the experimental and control groups. Then a post-test was administered to measure and analyze the effectiveness of the treatments in the experimental groups. The task was designed to be written using 150-200 words and to be done approximately in 20 minutes. Inter-rater reliability was run to assess the reliability of this test. The score of each participant was the average of the two scores given by each rater.

\section{Rubric}

Although the factors involved in performance assessment have further refined in later elaborations of the performance models (e.g. Fulcher, 2003), the original importance attached with the rater and rating scale is still maintained. A modified version of Cohen's (1994) scale 
was used for this study with a focus on five aspects of writing: Content, Organization, Language in use, Grammar, and Mechanics. The Content dimension includes the presence of main ideas, logical development of ideas, and supporting ideas with proper examples. The Organization dimension specifies the proper sequencing of ideas and the use of cohesive devices. The Language in use dimension focuses on the range of vocabulary and the use of proper register. The Grammar dimension refers to grammatical construction in terms of accuracy while the Mechanics dimension focuses on punctuation, spelling, capitalization, and indentation. Analytic scoring is indicated as a band score ranging from 1 to 5 for each section. So the maximum score for the writing task was 25 .

\section{Procedures for Data Collection and Analysis}

At the outset, a homogeneity test in terms of the participants' general proficiency was administered. The participants were randomly placed in three different groups. It is worth pointing out that the participants were randomized in order to control bias by all means. They were divided into two experimental groups and one control group. A pre-test of writing was prepared, piloted with 15 intermediate learners with the same characteristics of the target sample, and administered to all participants. After making sure of the homogeneity of the groups with respect to their paragraph writing ability, the two experimental groups received treatment. The focus, however, was different. Experimental group (A) and experimental group (B) used selfassessment and peer-assessment, respectively. In order to have sound self and peer-assessment, the criteria for assessing paragraphs were fully explained to the participants. Thus, students in group (A) began to assess themselves and in group (B) assessed each other. In the control group traditional teacher assessment was applied. Teacher took part in every writing activity and assessed them directly. The courses lasted for 10 sessions, one hour a week. After carrying out the treatments, a post-test was given to the participants in order to scrutinize the results and to measure the progress from pre-test to post-test and the effectiveness of the treatments in the experimental groups. Notably, the post-test was in the same level as the pretest. A one-way ANOVA was run again to compare the means of the three groups in the posttest. The detailed structure of the differences was investigated through doing multiple comparisons.

\section{Results and Discussion}

To investigate whether the groups differed at the pre-test stage, a one-way ANOVA was run on the pre-test scores. Table 1 below represents the related data.

Table 1

One-way ANOVA for the Pre-test Scores of the Control and Experimental Groups

\begin{tabular}{lccccc}
\hline & Sum of Squares & df & Mean Square & F & Sig. \\
\hline Between Groups & 3.078 & 2 & 1.539 & .276 & .760 \\
Within Groups & 234.367 & 42 & 5.580 & & \\
Total & 237.444 & 44 & & & \\
\hline
\end{tabular}


Based on Table 1, there was no significant difference between the mean scores of the three groups in pre-test of writing ( $p \geq .05$ ). In other words, the groups were almost at the same level of proficiency in terms of their writing skill at the beginning of the study before introducing the specific treatments.

Another one-way ANOVA was run on the post-test scores to investigate the possible difference of the groups on the post-test. Table 2 displays this analysis.

Table 2

ANOVA for the Results of the Writing Test (Post-test)

\begin{tabular}{lccccc}
\hline & Sum of Squares & df & Mean Square & F & Sig. \\
\hline Between Groups & 88.433 & 2 & 44.217 & 6.954 & .002 \\
Within Groups & 267.067 & 42 & 6.359 & & \\
Total & 355.500 & 44 & & & \\
\hline
\end{tabular}

The results of the post-test showed that the mean of group $1(\mathrm{M}=18.06)$, the mean of group 2 $(M=20.80)$, and the mean of group $3(M=17.63)$, differed significantly. The significance value of the $F$ test in the ANOVA table was less than (.05). Thus, the results showed that types of assessment significantly affect Iranian intermediate EFL learners' writing ability (F 2, $42=$ 6.954 , Sig. $=.002 \leq .05$ ). After verifying that the three groups differed in some way, the detailed structure of the differences was investigated through doing multiple comparisons. In other words, Post- Hoc test (Scheffe) was run to compare the means of the three groups to provide answer to the third research question. The comparison of the result is presented in Table 3.

Table 3

Multiple Comparisons for the Results of the Post-test of Writing Scheffe

(I) Groups

\begin{tabular}{|c|c|c|c|c|c|c|}
\hline \multirow{3}{*}{ (I) Groups } & \multirow{3}{*}{ (J) Groups } & \multirow{3}{*}{$\begin{array}{c}\text { Mean } \\
\text { Difference (I-J) }\end{array}$} & \multirow{3}{*}{$\begin{array}{l}\text { Std. } \\
\text { Error }\end{array}$} & \multirow{3}{*}{ Sig. } & \multicolumn{2}{|c|}{ Interval } \\
\hline & & & & & Lower & Upper \\
\hline & & & & & Bound & Bound \\
\hline \multirow[t]{2}{*}{$\begin{array}{l}\text { group 1( self- } \\
\text { assessment) }\end{array}$} & $\begin{array}{l}\text { group } 2 \text { (peer } \\
\text { assessment) }\end{array}$ & $-2.73333^{*}$ & .92078 & .018 & -5.0700 & -.3967 \\
\hline & $\begin{array}{c}\text { group } 3 \text { (control } \\
\text { group) }\end{array}$ & .43333 & .92078 & .895 & -1.9033 & 2.7700 \\
\hline \multirow[t]{2}{*}{$\begin{array}{l}\text { group } 2 \text { (peer } \\
\text { assessment) }\end{array}$} & $\begin{array}{l}\text { group 1( self- } \\
\text { assessment) }\end{array}$ & $2.73333^{*}$ & .92078 & .018 & .3967 & 5.0700 \\
\hline & $\begin{array}{c}\text { group } 3 \text { (control } \\
\text { group) }\end{array}$ & $3.16667^{*}$ & .92078 & .005 & .8300 & 5.5033 \\
\hline \multirow[t]{2}{*}{ group 3 (control group) } & $\begin{array}{l}\text { group 1( self- } \\
\text { assessment) }\end{array}$ & -.43333 & .92078 & .895 & -2.7700 & 1.9033 \\
\hline & $\begin{array}{l}\text { group } 2 \text { (peer } \\
\text { assessment) }\end{array}$ & $-3.16667^{*}$ & .92078 & .005 & -5.5033 & -.8300 \\
\hline *. The mean difference & iificant at the 0.0 & & & & & \\
\hline
\end{tabular}

The lowest mean difference was reported for the first experimental group that received selfassessment and the control group that received traditional teacher assessment (mean difference $=$ 
.433). The results showed that there was not statistically significant difference between the mean scores of the control group and the first experimental group that received self-assessment. This supported the first null hypothesis and implied that self-assessment does not have any significant impact on Iranian EFL learners' writing ability $(\mathrm{P} \geq .05)$.

On the other hand, the highest mean difference was found between the second experimental group that received peer-assessment and the control group that received traditional teacher assessment with the mean difference of (mean difference $=3$. 166). Moreover, the mean difference between the first and second experimental groups came to (mean difference $=2.7333$ ) that was statistically significant. The results of the Post- Hoc Scheffe test showed that there was statistically significant difference between the mean scores of the control group and the second experimental group that received peer-assessment. This rejected the second null hypothesis and implied that peer-assessment had statistically significant impact on Iranian EFL learners' writing ability.

The results of the Post- Hoc Scheffe test for the post-test of writing indicated that there was a significant difference in post-test scores between the first and second experimental groups. As it was displayed in Table 3, the mean difference between "self- assessment group" and the "peerassessment group" came to (2.7333). Although the participants in the two experimental groups were homogenous in terms of their writing as revealed by the results of the statistical analysis for the pre-test scores, they differed significantly in their post-test after receiving different types of assessment for their writing performance. The level of significance was lower than $(\alpha=.05)$ that showed the difference between the two groups was not simply due to chance variation and rejected the third null hypothesis suggesting that there was a statistically significant difference between the effects of self-assessment and peer-assessment on Iranian Intermediate EFL learners.

Based on these findings, self, peer and teacher-assessment of English writing improved Iranian intermediate EFL learners' writing performance. However, peer-assessment significantly affected the EFL learners' writing ability. In other words, the study revealed that peerassessment of English writing improved the participants' performance on writing test better than self-assessment and teacher-assessment of English writing. Additionally, the difference between the effects of self and peer-assessment were statistically significant $(\mathrm{P} \leq .05)$. Furthermore, the difference between the effects of peer- assessment and teacher- assessment was statistically significant $(\mathrm{P} \leq .05)$.

This study was set out with the aim of assessing the impact of self-assessment and peerassessment on Iranian EFL learners' paragraph writing ability. This study showed that there was no significant difference among the groups at the paragraph writing pre-test, whereas there were crucial differences among them at the post-test. It was noticed that self, peer and teacherassessment of English writing improved Iranian intermediate EFL learners' writing performance. However, peer-assessment significantly affected the EFL learners' writing ability. The mean score obtained by each of the three groups on the paragraph writing post-test indicated that both experimental groups obtained high mean scores; however, the second experimental group that 
used the peer-assessment achieved a higher mean score (20.79 versus 18.06 respectively). Peerassessment is more about learning than about assessment (Liu \& Carless, 2006). The findings of this study confirm the conclusion by Langan et al. (2005) which believed in the advantages of peer-assessment in students' future courses. Generally, most students had a positive take on the use of peer-assessment. However, some concerns and reservations, for example, differences between the L1 writing classroom and the classroom may arise due to cultural issues, where some students are accustomed to a very teacher-fronted classroom and do not feel comfortable working with peers in a more student-centered environment (Carson \& Nelson, 1994; Ramanathan \& Atkinson, 1999).

The results of the present study are in line with Wikstorm's (2007) study in which peerassessment was considered as an interactive type of assessment in which learners keep up with their teachers to achieve the goal. In fact, teachers are not the only assessors and not more the center of the assessment. The findings are in line with Ashraf and Mahdinezhad (2015) who examined the role of peer-assessment versus self-assessment in promoting autonomy in language use with a focus on speaking skill on EFL Iranian learners with the similar level of proficiency. The results of data analysis showed the positive effect of peer-assessment on leaners' autonomy. The results are also in agreement with the one carried out by Enayat, Iraji and Momeni (2016) who investigated the effects of self- and peer-assessment on Iranian EFL learners' argumentative writing performance. By providing alternative assessment techniques, learners could write better compositions. These studies are the same in nature and both deal with the written skill. This study is congruent with the one conducted by Puegphrom and Chiramanee (2011) which examined the efficiency of implementing peer-assessment on students' writing proficiency. According to the finding of the present study, this can be attributed to the fact that in the process of peer assessment, learners could learn from the peers' errors and make use of them in composing their own work. They also better earned and remembered grammatical rules leading to their writing ability improvement with fewer errors. Eventually the number of error decreased to the minimal or none existence. This is a confirmation of alternative assessment rather than traditional teacher assessment. Beaven (1977) also argued that learners had ample opportunities to see the errors made in the writing they assessed and made use of such errors in improving their own writing ability.

Moreover, these findings are in sharp contrast to the ones in Zarei and Uselfi's (2015) study which found no significant differences among the effects self, of peer, and teacher-assessment on learners' self-regulation. The findings of this study expressed a number of factors could possibly account for these findings. One of the reasons may be the Iranian socio-cultural educational setting, in which students are used to follow teachers' instructions and most classes are teachercentered.

\section{Conclusion}

This study attempted to examine the effect of self-assessment and peer- assessment in improving paragraph writing ability of intermediate EFL learners. The findings of the study showed that 
both self-assessment and peer-assessment have positive effects on the learners' writing ability. However, their effects are different from each other. Based on the results of this study, experimental group (B) who received the use of peer-assessment made more improvement in the post-test of writing. In other words, the use of peer-assessment leads to more proficiency in writing among Iranian intermediate EFL learners. Hence, the first and third hypotheses were supported but the second null hypothesis proposed at the beginning of the study was rejected.

It would be better if teachers move away from traditional assessment and focus more on various sorts of alternative assessment. The study suggested that learners have the ability to assess writing performance of their peers in appropriate conditions. These conditions consist of the clear provision of task-related criteria, sufficient training and recognizing learners' perception. Not only the product of assessment but also the process of being involved in self-and peer-assessment practices can enhance paragraph writing ability.

\section{References}

Ahangari, S., Rassekh-Alqol, B., \& Ali Akbari, H. (2013). The effect of peer- assessment on oral presentation in an EFL context. International Journal of Applied Linguistics \& English Literature, 2(3), 45-54.

Alderson, J. C. (1985). Evaluation: A way of involving the learner. Lancaster Practical Papers in English Language Education, 6, 45-80.

Andrade, H. \& Du, Y. (2007). Student responses to criteria-referenced self-assessment. Assessment and Evaluation in Higher Education, 32(2), 159-181.

Aydin, S. (2010). A qualitative research on portfolio keeping in English as a foreign language writing. The Qualitative Report, 3(15), 475-488.

Ashraf, H. \& Mahdinezhad, M. (2015). The Role of peer-assessment versus self-assessment in promoting autonomy in language use: Iranian Journal of Language Testing, 5(2), 53-71.

Beaven, M. H. (1977). Individualized goal-setting, self-evaluation and peer evaluation. In C. R. Cooper \& L. Odell (Eds.). Evaluating writing: Describing, measuring, judging (pp. 135-156). National Council of Teacher of English.

Belle, D. (1999). “Traditional assessment versus alternative assessment”. Master's Thesis, Kean University of New Jersey, ED431012 Online webpage citation. Retrieved from: http://edres.org/eric/ED431012

Benson, P. (2001). Teaching and researching autonomy in language learning. London: Longman.

Besharati, C. (2004). The impact of alternative assessment techniques on Iranian students' achievements in listening comprehension skill. Unpublished M.A. thesis, Al-Zahra University, Tehran, Iran.

Birjandi, P., \& Hadadi Tamjid, N. (2010). The Role of Self-assessment in Promoting Iranian EFL Learners' Motivation. English Language Teaching, 3(3), 211-220.

Carson, J. G. \& Nelson, G. L. (1994). Writing groups: Cross-cultural issues. Journal of Second Language Writing, 3, 17-30.

Cheng, W. \& Warren, M. (2005). Peer assessment of language proficiency. Edward Arnold publishers.

Cohen, A. D. (1994). Assessing language ability in the classroom. (2nd Ed.). Boston, MA: Heinle and Heinle.

Coombe, C, Folse, K, \& Hubly, N. (2007). Assessing English language learners. United States of America: University of Michigan Press.

Cowan, J. (2005). Developing the ability for making evaluative judgments. Teaching in Higher Education, 15(3), 323-334.

Crooks, T. (2001). The validity of formative assessment. Paper presented to the British

educational research association annual conference, University of Leeds, 13-15.

Dikel, M. R. (2005). A guide to going online for self-assessment tools: A critical view. An assessment in Language, 6(5), 64-74. Retrieved from:

www.rileyguide.com/assess.html.

Driscoll, M. P. (2000). Psychology of learning for instruction. Allyn \& Bacon, Needham Heights, Massachusetts: A Pearson Education Company. 
Elwood, J. \& Klonowski, V. (2002). Creating communities of shared practice: The challenges of assessment use in learning and teaching. Assessment \& Evaluation in Higher Education, 27, 243-256.

Iraji, H. R., Janebi Enayat, M. \& Momeni, M. (2016). The effect of self- and peer-assessment on Iranian EFL learners' argumentative writing performance. Theory and Practice in Language Studies, 6(4), 716-722.

Farhady, H. (2010). Research methods in applied linguistics. Tehran: Payame Noor University.

Firooz Zareh, A. R. (2006). The effectiveness of alternative assessment and traditional methods of testing on Iranian EFL adult learners' reading comprehency. Unpublished M.A. thesis, Allame Tabatab'I University, Tehran, Iran.

Fulcher, G. (2003). Testing second language speaking. London: Pearson Longman.

Hyland, K. (2003). Second language writing. New York, USA: Cambridge University Press.

Janisch, C., Liu, X., \& Akrofi, A. (2007). Implementing alternative assessment: Opportunities and obstacles. The Educational Forum, 71(3), 221-230.

Khansir, A. A., Ahrami, M., \& Hajivandi, A., (2013). The Study of errors in paragraph writing on Iranian EFL students. Middle-East Journal of Scientific Research, 16(2), 221-228.

Kollar, M., \& Fischer, B. (2010). Peer assessing writing. Cambridge, UK: Cambridge University Press.

Korkmaz, H., \& Kaptan, F. (2005). A study of computer based portfolio use in assessing students' developments. Teaching in Higher Education, 8(2), 186-201.

Law, B., \& Eckes, M. (2007). Assessment and ESL: An alternative approach. Winnipeg, Canada: Portage \& Main Press.

Lindsay, C. \& Knight, P. (2006). Learning and teaching English: A course for teachers. Oxford: Oxford University Press.

Liu, J. \& Hansen, J. (2002) Peer response in second language writing classrooms. USA: The University of Michigan Press.

Luoma, S. \& Tarnanen, M. (2003). Creating a self-rating instrument for L2 writing: from idea to implementation. Language Testing, 20(4), 440-465.

Lynn, F. (2011). The whole world guide to language learning and teaching.Yarmouth, ME: Intercultural Press.

Moon, T., \& Hughes, K. (2002). Training and scoring issues involved in large-scale writing assessments. Educational Measurement: Issues and Practice, 21, 15-19.

Moradan, A., \& Hedayati, N. (2011). The impact of portfolios and conferencing on Iranian EFL learners' writing skill. Journal of English Language Teaching and Learning, 8, 115-141.

Nakamura, Y. (2002). Teacher assessment and peer assessment in practice. Educational Studies, 44, 23-38.

Patri, M. (2002). The influence of peer feedback on self- and peer-assessment of oral skills. Language Testing, 19(2), 109-131.

Puegphrom, P. \& Chiramanee, T. (2011). The effectiveness of implementing peer assessment on students' writing proficiency. Practical Assessment Research \& Evaluation, 12, 1-10.

Ramanthan, V. \& Atkinson, D. (1999). Individualism, academic writing, and ESL writers. Journal of Second Language Writing, 8, 45-75.

Ryan, R. (2007). Motivation and emotion: A new look and approach for two reemerging fields. Motivation and Emotion, 31, 1-3.

Sluijsmans, D. M. A., Brand-Gruwel, S., vanMerrienboer, J. J. G., \& Bastiens, T. J. (2003). The training of peerassessment skills to promote the development of reflection skills in teacher education. Studies in Educational Evaluation, 29, 23-42.

Tan, K. (2007). Conceptions of self-assessment: What is needed for long term learning? In D. Boud \& N. Falchikov (Eds.), Rethinking assessment in higher education: Learning for the longer term (pp. 114-127). London: Routledge.

Tangdhanakanond, K. (2006). Authentic assessment. Journal of the Faculty of Education, Chulalongkorn University, 34(3), 1-13.

Weigle, S. C. (2002). Assessing writing. Cambridge: Cambridge University Press.

Wikström, M., (2007). Authentic assessment for language learners: Practical approach for language instructor. White plains, NY: Addison-Wesley.

Zarei, A. A., \& Uselfi, Z. (2015). On the effectiveness of three types of assessment on EFL learners' self-regulation. Journal of Research and development, 2(7), 304-312. 